\title{
Article \\ The Effect of Rumination Time on Milk Performance and Methane Emission of Dairy Cows Fed Partial Mixed Ration Based on Maize Silage
}

\author{
Robert Mikuła ${ }^{1, * \mathbb{D}}$, Marcin Pszczola ${ }^{2, * \mathbb{D}}$, Katarzyna Rzewuska ${ }^{2}$, Sebastian Mucha ${ }^{2}$, Włodzimierz Nowak ${ }^{1}$ and \\ Tomasz Strabel ${ }^{2}$ \\ 1 Department of Animal Nutrition, Poznań University of Life Sciences, Wołyńska 33, 60-637 Poznan, Poland; \\ wlodzimierz.nowak@up.poznan.pl \\ 2 Department of Genetics and Animal Breeding, Poznań University of Life Sciences, Wołyńska 33, \\ 60-637 Poznan, Poland; katarzyna.rzewuska@up.poznan.pl (K.R.); sebastian.mucha@up.poznan.pl (S.M.); \\ tomasz.strabel@up.poznan.pl (T.S.) \\ * Correspondence: robert.mikula@up.poznan.pl (R.M.); marcin.pszczola@up.poznan.pl (M.P.)
}

check for

updates

Citation: Mikuła, R.; Pszczola, M.; Rzewuska, K.; Mucha, S.; Nowak, W.; Strabel, T. The Effect of Rumination Time on Milk Performance and Methane Emission of Dairy Cows Fed Partial Mixed Ration Based on Maize Silage. Animals 2022, 12, 50. https://doi.org/10.3390/ ani12010050

Received: 30 September 2021 Accepted: 23 December 2021 Published: 27 December 2021

Publisher's Note: MDPI stays neutral with regard to jurisdictional claims in published maps and institutional affiliations.

Copyright: (C) 2021 by the authors. Licensee MDPI, Basel, Switzerland. This article is an open access article distributed under the terms and conditions of the Creative Commons Attribution (CC BY) license (https:// creativecommons.org/licenses/by/ $4.0 /)$.
Simple Summary: Greenhouse gas emission has attracted considerable public attention in recent years, driving the search for genetic, nutritional, and management strategies to reduce methane emissions and increase the sustainability of milk production. Rumination activity has an important function in feed particle size reduction, condition of feeding behavior, and feed intake as well as in stabilizing rumen fluid $\mathrm{pH}$ through saliva production. A total of 365 high-yielding Polish Holstein -Friesian multiparous dairy cows were included in the study covering 24 to 304 days of lactation. Next, the data from the cows were assigned to three groups based on daily rumination time: low rumination up to $412 \mathrm{~min}$ / day (up to 25th rumination percentile), medium rumination from 412 to $527 \mathrm{~min} /$ day (between the 25th and 75th percentile), and high rumination above $527 \mathrm{~min} /$ day (from the 75th percentile). We showed that a longer rumination time leads to a lower methane emission level. Therefore, strategies that increase chewing activity may be used to reduce the environmental impact of dairy cows production.

\begin{abstract}
The objective of this study was to determine the effect of the rumination time on milk yield and composition as well as methane emission during lactation in high-yielding dairy cows fed a partial mixed ration based on maize silage without pasture access. A total of 365 high-yielding Polish Holstein-Friesian multiparous dairy cows were included in the study covering 24 to 304 days of lactation. Methane emission, rumination time, and milk production traits were observed for the period of 12 months. Next, the data from the cows were assigned to three groups based on daily rumination time: low rumination up to $412 \mathrm{~min}$ /day (up to 25th rumination percentile), medium rumination from 412 to $527 \mathrm{~min} /$ day (between the 25th and 75th percentile), and high rumination above $527 \mathrm{~min} /$ day (from the 75th percentile). Rumination time had no effect on milk yield, energycorrected milk yield, or fat and protein-corrected milk yield. High rumination time had an effect on lower fat concentration in milk compared with the medium and low rumination groups. The

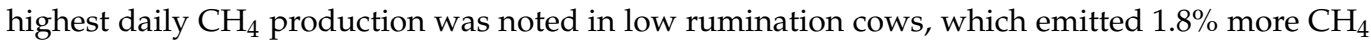
than medium rumination cows and $4.2 \%$ more than high rumination cows. Rumination time affected daily methane production per $\mathrm{kg}$ of milk. Cows from the high rumination group produced $2.9 \%$ less $\mathrm{CH}_{4}$ per milk unit compared to medium rumination cows and $4.6 \%$ in comparison to low rumination cows. Similar observations were noted for daily $\mathrm{CH}_{4}$ production per ECM unit. In conclusion, a longer rumination time is connected with lower methane emission as well as lower methane production per milk unit in high-yielding dairy cows fed a maize silage-based partial mixed ration without pasture access.
\end{abstract}

Keywords: rumination; chewing activity; milk production; methane emission; automatic milking 


\section{Introduction}

The milk production of dairy cows has increased substantially over the last few years due to selection as well as substantially improved nutrition and herd management. High production requires substituting forage with a high starch content concentrate to meet the high nutrient requirement as well as maintain rumen homeostasis. As a consequence, the contribution of crude fiber and physically effective neutral detergent fiber to the diet of high-yielding dairy cows has decreased. In turn, this can affect the rumination behavior. Rumination is desirable, as it takes part in breaking down of the feed particles and stimulates saliva production. Saliva lysozyme through preventing the proliferation of Gram-positive bacteria plays an important function on the rumen microbiota and can also influence the selection of methanogenic microorganisms and affect the rumen ecosystem and modulate methane emissions. Saliva also contains bicarbonate and phosphate buffers and plays an important role in sustaining the rumen fluid $\mathrm{pH}$ and cellulolytic microbial activity [1]. Thus, the optimal rumination activity is necessary to decrease the risk of rumen subacute and acute acidosis [2,3] as well as maintain good health status and lower incidences of clinical and subclinical disorders [4-7]. Rumination impacts the whole digestion process, including the feed passage rate as well as voluntary feed intake in dairy cows [8], while it may impact the cow's milk performance [9]. Watt et al. [10] showed that a longer rumination time improves feed intake, milk production, and total methane emission, while it also reduces methane emission per milk unit during the 22-day experimental period in grazing dairy cows.

Greenhouse gas emission by dairy farms has become the focus of public attention in recent years. The search for nutritional and management methods to reduce methane emission is necessary for sustainable milk production [11,12]. The rumen environment may affect methane synthesis by the rumen methanogens [13]. An increase in acetate and butyrate contents in the rumen fluid can affect the concentration of dissolved hydrogen utilized in methane synthesis [14]. The rise of acetate fermentation is related to the availability of crude fiber and creates a homeostatic environment related to fiber degradation bacteria [1]. As described above, rumination time due to its role in stabilizing $\mathrm{pH}$ of rumen fluid is related to the health status of cows and also can indirectly affect the rise of methane emission. In the available literature, the relationships between both phenotypes - rumination time and methane emission - has been described mainly in grazing dairy cows [10]. Despite other studies, which mainly focused on the description of genetics correlations between rumination time and methane emission, there is a lack of a study covering high-yielding dairy cows fed a diet based on maize silage during the whole lactation period. Additionally, results of the published experiments covered only a small part of lactation $[10,15]$ or were conducted on other than Polish Holstein-Friesian breed [16] or aimed to compare different methods of methane measurement [17], whereas the present study analyzed records from 24 to 304 days of lactation on 365 animals to provide a better overview of interactions between rumination activity, performance, and methane production.

We hypothesized that a longer rumination time is connected with lower methane emission per milk unit in high yielding dairy cows fed without pasture access.

The objective of this study was to determine the effect of the rumination time, milk yield, and composition along with methane emission during lactation in high-yielding dairy cows fed a maize silage-based partial mixed ration.

\section{Materials and Methods}

\subsection{Animal Management, Experimental Design, and Diet}

All animal procedures were conducted in accordance with the guidelines of the Polish Council for Animal Care and the Local Ethics Commission of the Poznań University of Life Sciences (Poznań, Poland) with respect to animal experimentation and care of the animals under the study. 
A total of 365 high-yielding (11,264 kg/305 days lactation) Polish Holstein-Friesian multiparous dairy cows were included in the study covering 24 to 304 days of lactation. In total, 14,274 daily complete (cow and all milk production traits) observations were collected. Data were collected in a production environment. Data from cows were assigned to three groups based on individual cow average daily rumination time (Figure 1): low rumination up to $412 \mathrm{~min} /$ day (L, up to the 25 th rumination percentile), medium rumination from 412 to $527 \mathrm{~min} /$ day (M, between the 25th and 75th percentile), and high rumination above $527 \mathrm{~min}$ /day ( $\mathrm{H}$, from the 75 th percentile).

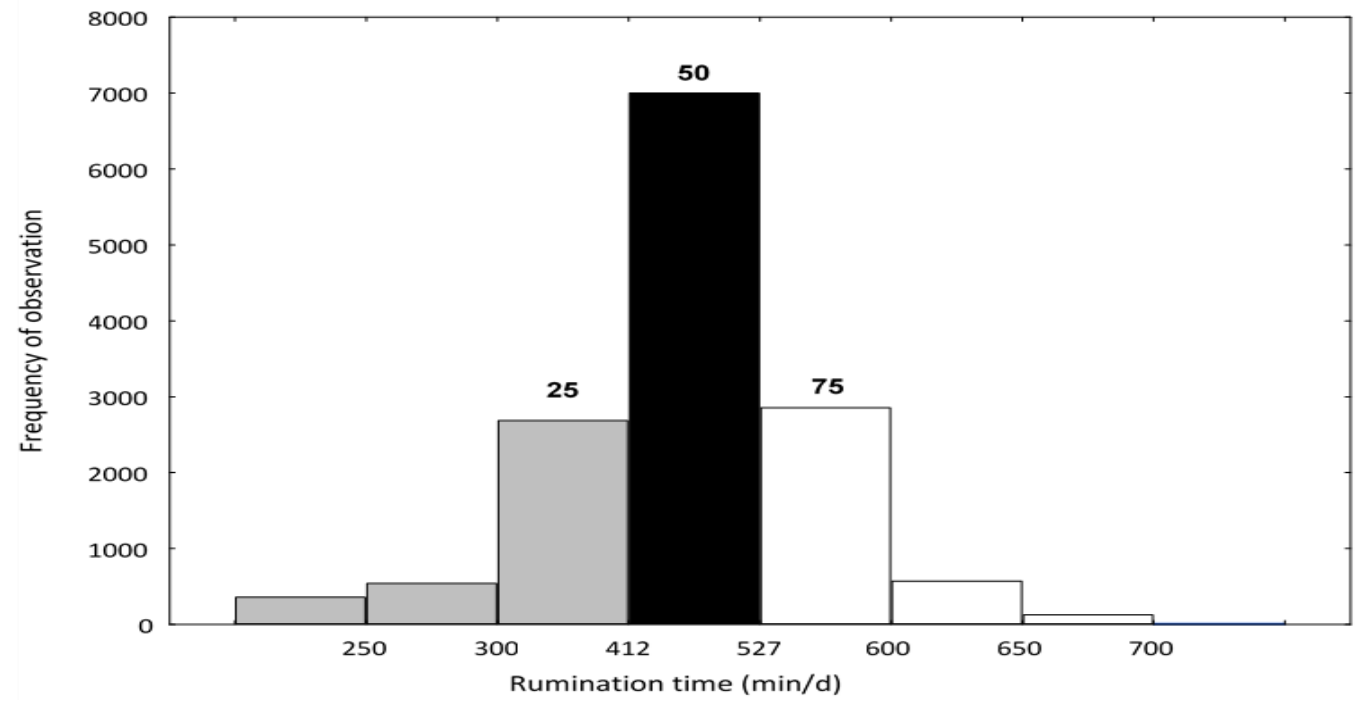

Figure 1. Frequency distribution of cows divided based on rumination time (min/day). Low rumination (L, grey color) to $412 \mathrm{~min} /$ day, medium rumination (M, black color) from 412 to $527 \mathrm{~min} /$ day, and high rumination $(\mathrm{H}$, white color) from $527 \mathrm{~min} /$ day.

The cows were milked in an automatic milking system (AMS, Astronaut, Lely Industries, NV, Maassluis, The Netherlands).

The cows received ad libitum a partial mixed ration (PMR), which was served twice a day and met requirements for $25 \mathrm{~kg}$ of milk yield. The animals had free and equal access to the feeding table. The cows were divided into two groups due to the management routine and not based on their characteristics. Each group had one common feeding table whose size was dependent on the number of the animals in the technological group.

The nutritional values of the feed components were calculated on the basis of the analyzed nutrient contents using NIRS (InfraXact, Foss, Hilleroed, Denmark) and the MAX $^{\mathrm{TM}}$ System for Dairy software (3.19, Cargill, Minneapolis, MN, USA). The diets were balanced according to the NRC (2001) system recommendations and the MAX ${ }^{\mathrm{TM}}$ System for Dairy software (3.19, Cargill, Minneapolis, MN, USA).

PMR and concentrates ingredients and nutritional value are shown in Table 1.

Two concentrates ( $C$ standard and $C$ extra) were added according to the requirements of individual cows from 0.5 to $8 \mathrm{~kg}$ into AMS during each milking. The proportion of $\mathrm{C}$ standard and $\mathrm{C}$ extra dispensed in AMS depended on individual milk yields and ranged from $75: 25$ to $70: 30$.

The silages were analyzed and verified two times per month using the NIRS method.

Weekly forage, concentrates, and PMR representative samples were collected, frozen, and stored $\left(-20^{\circ} \mathrm{C}\right)$ for further pooled monthly analyses using wet chemistry methods. On the basis of crude protein (CP, method 976.05; AOAC International, 2005), neutral detergent fiber (NDF, PN-EN ISO 16472:2007), and acid detergent fiber (ADF, PN-EN ISO 13906:2009), feeds as well as the PMR were verified. The PMR values were recalculated monthly or before a new forage from a new silo was used. 
The particle size distribution of PMR samples was determined weekly by the Penn State Particle Separator system with 3 sieves (19 mm, $8 \mathrm{~mm}, 1.18 \mathrm{~mm}$ ) and a bottom pan [18]. The mean retention of particles were: $6 \%$ (>19 mm), $48 \%(8-19 \mathrm{~mm}), 40.5 \%(1.8-8 \mathrm{~mm})$, and $5.5 \%(<1.18 \mathrm{~mm})$.

Table 1. Average ingredients and nutrient composition of the experimental partial mixed ration diet (PMR) and concentrates ( $\mathrm{C}$ standard, $\mathrm{C}$ extra).

\begin{tabular}{|c|c|}
\hline Items & \\
\hline \multicolumn{2}{|l|}{ PMR } \\
\hline \multicolumn{2}{|l|}{ Ingredients, $\mathrm{g} / \mathrm{kg} \mathrm{DM}$} \\
\hline maize silage & 337 \\
\hline alfalfa silage & 149 \\
\hline wheat straw & 91 \\
\hline wheat grain & 81 \\
\hline sugar beet pulp silage & 81 \\
\hline brewer's grain silage & 76 \\
\hline maize grain silage & 69 \\
\hline rapeseed meal & 61 \\
\hline ProStim Soy balance & 18 \\
\hline minerals, vitamins, and feed additives & 37 \\
\hline \multicolumn{2}{|l|}{ Nutritional value, in $\mathrm{kg}$ DM } \\
\hline $\mathrm{NEL}_{3 \mathrm{x}}$ & $1.49 \mathrm{Mcal} / \mathrm{kg}$ \\
\hline $\mathrm{CP}$ & $150 \mathrm{~g} / \mathrm{kg}$ \\
\hline RUP & $35 \%$ \\
\hline NDF & $356 \mathrm{~g} / \mathrm{kg}$ \\
\hline $\mathrm{ADF}$ & $223 \mathrm{~g} / \mathrm{kg}$ \\
\hline NFC & $370 \mathrm{~g} / \mathrm{kg}$ \\
\hline \multicolumn{2}{|l|}{ C standard } \\
\hline \multicolumn{2}{|l|}{ Nutritional value, in $\mathrm{kg}$ DM } \\
\hline $\mathrm{NEL}_{3 x}$ & $1.73 \mathrm{Mcal} / \mathrm{kg}$ \\
\hline $\mathrm{CP}$ & $220 \mathrm{~g} / \mathrm{kg}$ \\
\hline \multicolumn{2}{|l|}{ C extra } \\
\hline \multicolumn{2}{|l|}{ Nutritional value, in $\mathrm{kg}$ DM } \\
\hline $\mathrm{NEL}_{3 \mathrm{x}}$ & $1.99 \mathrm{Mcal} / \mathrm{kg}$ \\
\hline $\mathrm{CP}$ & $267 \mathrm{~g} / \mathrm{kg}$ \\
\hline
\end{tabular}

DM-dry matter; NEL—Net Energy Lactation; CP—crude protein; RUP—rumen undegraded protein; NDFneutral detergent fiber; ADF-acid detergent fiber; NFC—non-fiber carbohydrates; ProStim Soy balance-soybean meal, brewer's grain, urea, $1.79 \mathrm{Mcal} \mathrm{NEL}_{3 \mathrm{x}}, \mathrm{CP} 784 \mathrm{~g} / \mathrm{kg}$ DM; minerals, vitamins, and feed additives—sodium $12.5 \%$, calcium $13.2 \%$, phosphorus $2.5 \%$, vit. A $220,000 \mathrm{IU}$, vit. $\mathrm{D}_{3} 50,000 \mathrm{IU}$, vit. E $850 \mathrm{mg} / \mathrm{kg}$, niacin $7800 \mathrm{mg} / \mathrm{kg}$, vit. $B_{12} 700 \mu \mathrm{g} / \mathrm{kg}$, biotin $21,000 \mu \mathrm{g} / \mathrm{kg}$, folic acid $20 \mathrm{mg} / \mathrm{kg}$, magnesium $64 \mathrm{~g} / \mathrm{kg}$, iron $310 \mathrm{mg} / \mathrm{kg}$, manganese $2000 \mathrm{mg} / \mathrm{kg}$, copper $500 \mathrm{mg} / \mathrm{kg}$, zinc $2340 \mathrm{mg} / \mathrm{kg}$, iodine $44 \mathrm{mg} / \mathrm{kg}$, cobalt $8.8 \mathrm{mg} / \mathrm{kg}$, selenium $10 \mathrm{mg} / \mathrm{kg}$, copper organic $220 \mathrm{mg} / \mathrm{kg}$, manganese organic $440 \mathrm{mg} / \mathrm{kg}$, zinc organic $1320 \mathrm{mg} / \mathrm{kg}$, selenium organic $2.5 \mathrm{mg} / \mathrm{kg}$, vit. E total $1800 \mathrm{mg} / \mathrm{kg}$, proviox eqw vit. E $1800 \mathrm{mg} / \mathrm{kg}$, mycofix plus $18 \mathrm{~g} / \mathrm{kg}$, Diamond XP LS 20,000 mg/kg, klinoptylolit $82,976 \mathrm{mg} / \mathrm{kg}$, bentonite $5400 \mathrm{mg} / \mathrm{kg}$, S. cerevisiae 70,000,001,024 cfu $/ \mathrm{kg}$; both concentrates based on soybean meal, rapeseed meal, corn, wheat and barley grains, barley germ.

\subsection{Rumination Time, Milk Performance, Body Weight}

Rumination time was measured using electronic rumination loggers placed on the neck collars (SCR Engineers Ltd., Netanya, Israel). Loggers recorded rumination data in $2 \mathrm{~h}$ intervals (i.e., 12 values per day), and rumination time was expressed in minutes of rumination time recorded within each time interval. The data for rumination with accuracy (rumination mark) were read from the loggers by the readers placed in the barn connected with the Lely T4C. The daily rumination time of cow was calculated by adding 12 measurements from the day. Measurements with low accuracy (rumination mark below 98) were rejected, and all the rumination time observations of a particular cow recorded 
at that day were removed from the dataset (i.e., $12 \%$ of daily rumination time was set to missing).

Daily milk production, fat, and protein content were obtained from the farm management system (Lely T4C) and then used for calculating energy-corrected milk (ECM) and fat protein-corrected milk (FPCM). The ECM was calculated according to Reist et al. [19] as $[(0.038 \times$ g crude fat $+0.024 \times$ g crude protein $+0.017 \times$ g lactose $)] \times \mathrm{kg}$ milk $/ 3.14$. The FPCM was calculated as $[(0.337+0.116 \times$ milk fat $\%+0.06 \times$ milk protein $\%) \times \mathrm{kg}$ of milk] [20].

Body weight was collected in automatic scales, and therefore, some additional filtering of the data was required. For that, data from each cow were checked separately. First, the median body weight (BW) for a cow was calculated. Second, BW values lower than $100 \mathrm{~kg}$ than the cow's median BW were set to missing, as such a difference was assumed to be an erroneous record. This was confirmed by the visual inspection of the data (now shown). Third, the missing BW records were substituted by the cow's median BW.

The AMS identified each animal during milking and saved daily information concerning body weight and milk performance.

\subsection{Methane Measurements}

The $\mathrm{CH}_{4}$ concentration (ppm) was measured in the air exhaled by the cows during milking in AMS using an Fourier transform infrared spectroscopy FTIR analyzer (GASMET 4030; Gasmet Technologies Oy, Helsinki, Finland) installed in the feeding bin. The samples were taken continuously, and the gas samples were analyzed every $5 \mathrm{~s}$. The investigated phenotypes were daily averages obtained as described in Pszczola et al. [21]. First, the concentrations from the whole milking were averaged. Secondly, the measurements from all milkings were corrected for the diurnal variation in $\mathrm{CH}_{4}$. Subsequently, the corrected measurements for each cow were averaged within the day. Then, methane production was calculated in L/day following Madsen et al. [22] based on the ratios between $\mathrm{CH}_{4}$ and $\mathrm{CO}_{2}$ concentrations measured during each milking and estimated heat production.

The following average daily phenotypes were defined and analyzed: methane production $\left(\mathrm{CH}_{4}\right)(\mathrm{L})$, the $\mathrm{CH}_{4}$ production in relation to metabolic weight $\left(\mathrm{CH}_{4} / \mathrm{BW}^{0.75}\right)(\mathrm{L} / \mathrm{kg})$, milk production $\left(\mathrm{CH}_{4} /\right.$ milk $)(\mathrm{L} / \mathrm{kg})$, energy-corrected milk $\left(\mathrm{CH}_{4} / \mathrm{ECM}\right)(\mathrm{L} / \mathrm{kg})$, and per concentrate intake $\left(\mathrm{CH}_{4}\right.$ / concentrate intake) $(\mathrm{L} / \mathrm{g})$.

\subsection{Statistical Analysis}

Rumination time was divided into three groups according to the quartile distribution. Cows below the first quartile of rumination time were assigned to the low-L group, cows between the first and third quartile were assigned to the medium-M group, and cows above the third quartile of rumination time were placed in the high-H group.

Differences between rumination groups were assessed for each of the analyzed traits separately.

To check whether rumination time has an impact on the analyzed traits, the following model was employed:

$$
y_{i j k l}=G_{R O U P}+L A C_{k} \times \sum_{n=1}^{5} \beta_{n} D I M_{l n}+\text { cow }_{i}+\text { error }_{i j k l},
$$

where $y_{i j k l}$ was one of the following traits (i.e., daily rumination time, body weight, metabolic body weight, concentrate intake, concentrate intake per $\mathrm{kg}$ of milk, concentrate intake per metabolic weight, daily milk yield, energy-corrected milk yield, fat proteincorrected milk yield, fat, protein and lactose concentration, fat to protein ratio, daily methane production, daily methane production per metabolic weight, daily methane production per milk production, and daily methane production per concentrate intake) observed on the $i$ th cow assigned to the $j$ th group of rumination level (GROUP). The overall lactation curve was modeled with fourth-order Legendre polynomials separately for first, 
second, and further lactations. The GROUP had three levels: High, Medium, and Low. The terms cow and error were random terms.

The analyses were performed in R software [23]. The model effects were estimated using lme4 package [24], the significance of the difference between estimated marginal means was assessed using lmerTest [25] and emmeans packages [26] using Satterthwaite's method [27] for approximating degrees of freedom enabling testing for the significance of differences between fixed effects levels. The $p$-values obtained for the differences between the estimated marginal means for rumination groups were adjusted using Tukey's method for comparing 3 estimates.

\section{Results}

Differences in rumination time were observed between all the groups $(\mathrm{H}, \mathrm{M}$, and $\mathrm{L})$ (Figure 2). The average daily rumination time was 195 min longer for cows in the Hroup in comparison to the L group and 84 min greater compared to cows, which belonged to the medium rumination time group (M) (Table 2). Mean body weight differed significantly between all the groups (H: $543 \mathrm{~kg}, \mathrm{M}: 546 \mathrm{~kg}$, L: $551 \mathrm{~kg})$. The intake of concentrate from AMS was higher in low rumination cows compared to the other groups. High rumination cows were characterized by the lowest concentrate intake per their metabolic body weight $\left(\mathrm{BW}^{0.75}, 39.58 \mathrm{~g} / \mathrm{kg}\right)$ and differed both from medium rumination $(40.34 \mathrm{~g} / \mathrm{kg})$ and low rumination cows $(40.32 \mathrm{~g} / \mathrm{kg})$. Rumination time had no effect on concentrate intake on milk yield.

Table 2. Estimated marginal means for rumination time, body weight, and concentrate intake of low $(\mathrm{L})$, medium $(\mathrm{M})$, and high $(\mathrm{H})$ rumination cows.

\begin{tabular}{|c|c|c|c|c|}
\hline \multirow{2}{*}{ Variable } & \multicolumn{3}{|c|}{ Rumination Group } & \multirow{2}{*}{ SD } \\
\hline & $\mathbf{L}$ & $\mathbf{M}$ & $\mathbf{H}$ & \\
\hline No. observations & 3650 & 7029 & 3595 & N.A. \\
\hline Rumination time (min/day) & $356.39^{a}$ & $467.30^{\mathrm{b}}$ & $551.06^{c}$ & 94.81 \\
\hline $\mathrm{BW}(\mathrm{kg})$ & $551.46^{\mathrm{a}}$ & $545.80^{\mathrm{b}}$ & $543.44^{\mathrm{C}}$ & 85.87 \\
\hline $\mathrm{BW}^{0.75}(\mathrm{~kg})$ & $113.21^{a}$ & $112.35^{b}$ & $112.01^{\mathrm{b}}$ & 13.39 \\
\hline Concentrate intake (g/day) & $4360^{a}$ & $4264^{\mathrm{b}}$ & $4239^{b}$ & 1368 \\
\hline Concentrate intake/milk yield $(\mathrm{g} / \mathrm{kg})$ & 123.73 & 121.65 & 120.97 & 53.12 \\
\hline Concentrate intake $\mathrm{BW}^{0.75}(\mathrm{~g} / \mathrm{kg})$ & $40.32^{\mathrm{a}}$ & $40.34^{\mathrm{a}}$ & $39.58^{b}$ & 11.99 \\
\hline
\end{tabular}

a-c Estimated marginal means within a row with different superscripts differ significantly $(p<0.05)$; Low rumination (L) to $412 \mathrm{~min} /$ day, medium rumination $(\mathrm{M})$ from 412 to $527 \mathrm{~min} /$ day, and high rumination $(\mathrm{H})$ from $527 \mathrm{~min} /$ day; SD_overall standard deviation.

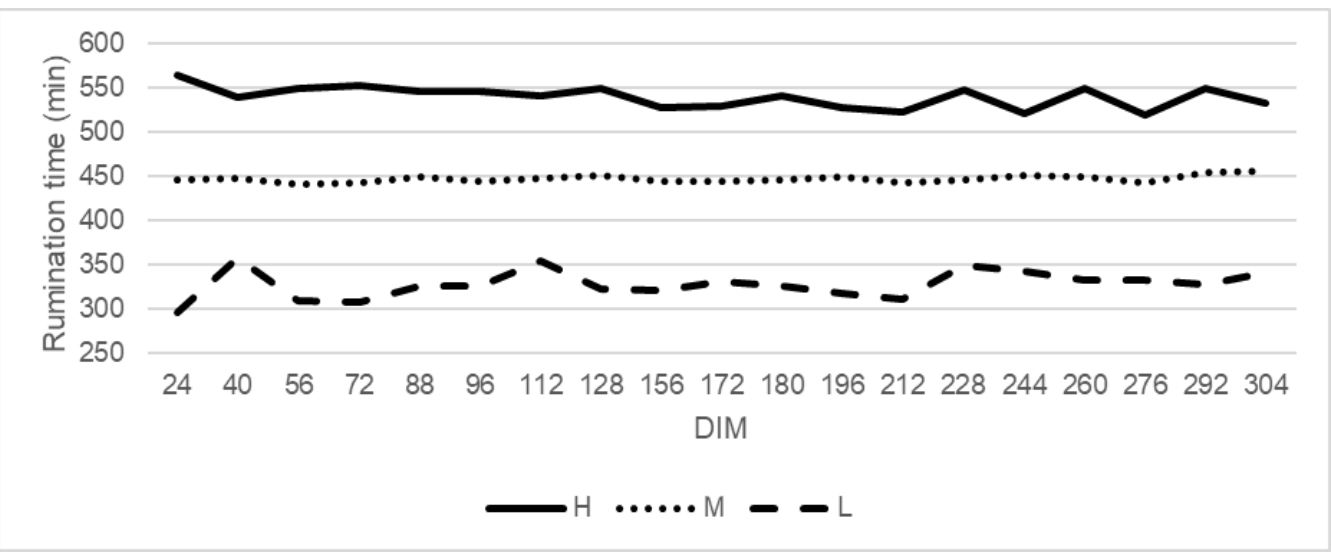

Figure 2. The trend of rumination time by cows classified as high (H), medium (M), and low (L) rumination animals. High rumination $(\mathrm{H})$ from $527 \mathrm{~min} /$ day, medium rumination $(\mathrm{M})$ from 412 to $527 \mathrm{~min} /$ day, and low rumination (L) to $412 \mathrm{~min} /$ day. 
Rumination time had no effect on milk, energy-corrected milk, as well as fat and protein-corrected milk yield (Table 3 ). High rumination cows had an effect on lower fat concentration in milk (3.75\%) compared with the M and L groups (3.94\% and 3.80\%, respectively). Differences between rumination time groups on protein and lactose concentrations in milk were not confirmed. The fat and protein ratio was lower in high rumination cows (1.14) compared to the low (1.15) and medium (1.15) rumination cows. Rumination time had no effect on the number of milkings in AMS, which were on average 2.85 per day.

Table 3. Estimated marginal means for milk and methane production phenotypes of low (L), medium $(\mathrm{M})$, and high $(\mathrm{H})$ rumination cows.

\begin{tabular}{|c|c|c|c|c|}
\hline \multirow{2}{*}{ Phenotypes } & \multicolumn{3}{|c|}{ Rumination Groups } & \multirow{2}{*}{ SD } \\
\hline & $\mathbf{L}$ & $\mathbf{M}$ & $\mathbf{H}$ & \\
\hline \multicolumn{5}{|c|}{ Milk production, composition and AMS use } \\
\hline Milk (kg/day) & 35.46 & 35.28 & 35.26 & 7.84 \\
\hline ECM (kg/day) & 34.42 & 34.31 & 34.17 & 6.88 \\
\hline FPCM (kg/day) & 33.95 & 33.83 & 33.70 & 6.81 \\
\hline Fat $(\%)$ & $3.80^{\mathrm{a}}$ & $3.94^{\mathrm{a}}$ & $3.75^{b}$ & 0.55 \\
\hline Protein $(\%)$ & 3.29 & 3.30 & 3.29 & 0.18 \\
\hline Lactose $(\%)$ & 4.97 & 4.97 & 4.97 & 0.11 \\
\hline Fat: protein & $1.15^{\mathrm{a}}$ & $1.15^{\mathrm{a}}$ & $1.14^{\mathrm{b}}$ & 0.17 \\
\hline Milkings/day & 2.84 & 2.84 & 2.86 & 0.81 \\
\hline \multicolumn{5}{|l|}{ Daily methane production } \\
\hline $\mathrm{CH}_{4}(\mathrm{~L})$ & $412.47^{\mathrm{a}}$ & $404.99^{b}$ & $395.80^{c}$ & 87.16 \\
\hline $\mathrm{CH}_{4} / \mathrm{BW}^{0.75}(\mathrm{~L} / \mathrm{kg})$ & $3.68^{\mathrm{a}}$ & $3.67^{\mathrm{a}}$ & $3.59^{b}$ & 0.78 \\
\hline $\mathrm{CH}_{4} / \mathrm{milk}(\mathrm{L} / \mathrm{kg})$ & $12.07^{\mathrm{a}}$ & $11.86^{\mathrm{b}}$ & $11.52^{\mathrm{c}}$ & 3.49 \\
\hline $\mathrm{CH}_{4} / \mathrm{ECM}(\mathrm{L} / \mathrm{kg})$ & $12.26^{\mathrm{a}}$ & $12.07^{\mathrm{b}}$ & $11.79^{c}$ & 3.29 \\
\hline $\mathrm{CH}_{4} /$ concentrate intake $(\mathrm{L} / \mathrm{g})$ & $0.10^{\mathrm{a}}$ & $0.12^{b}$ & $0.11^{\mathrm{ab}}$ & 0.15 \\
\hline
\end{tabular}

The significant effect of rumination time on methane $\left(\mathrm{CH}_{4}\right)$ emission was observed in all the groups. The highest daily $\mathrm{CH}_{4}$ production was noted in low rumination cows $(412.47 \mathrm{~L})$, which emitted $1.8 \%$ more $\mathrm{CH}_{4}$ than medium rumination cows $(404.99 \mathrm{~L})$ and $4.2 \%$ more than low rumination cows $(395.80 \mathrm{~L})$. The cows from the high rumination group had a lower daily $\mathrm{CH}_{4}$ production per $\mathrm{BW}^{0.75}(3.59 \mathrm{~L} / \mathrm{kg})$ compared to both groups, medium rumination cows $(3.67 \mathrm{~L} / \mathrm{kg})$ and low rumination cows $(3.68 \mathrm{~L} / \mathrm{kg})$.

Rumination time had a positive effect on daily methane production per $\mathrm{kg}$ of milk. Cows from the high rumination group produced less daily $\mathrm{CH}_{4}$ per $\mathrm{kg}$ of milk $(11.52 \mathrm{~L} / \mathrm{kg})$ compared to medium $(11.86 \mathrm{~L} / \mathrm{kg})$ and low $(12.07 \mathrm{~L} / \mathrm{kg})$ rumination cows. Similar observations were noted for daily $\mathrm{CH}_{4}$ production per ECM unit $(11.79 \mathrm{~L} / \mathrm{kg}, 12.07 \mathrm{~L} / \mathrm{kg}$, $12.26 \mathrm{~L} / \mathrm{kg}$ ). Daily lower methane production per concentrate intake unit was highest in medium rumination cows $(0.12 \mathrm{~L} / \mathrm{g})$ compared to the $\mathrm{L}$ group $(0.10 \mathrm{~L} / \mathrm{g})$.

Daily methane yield $(\mathrm{kg})$ was higher at the beginning of the lactation and decreased toward the end of the milking period (Figure 3), whereas the methane production per $\mathrm{kg}$ of milk was low at the beginning of the lactation and increased toward the end of the lactation (Figure 4). 


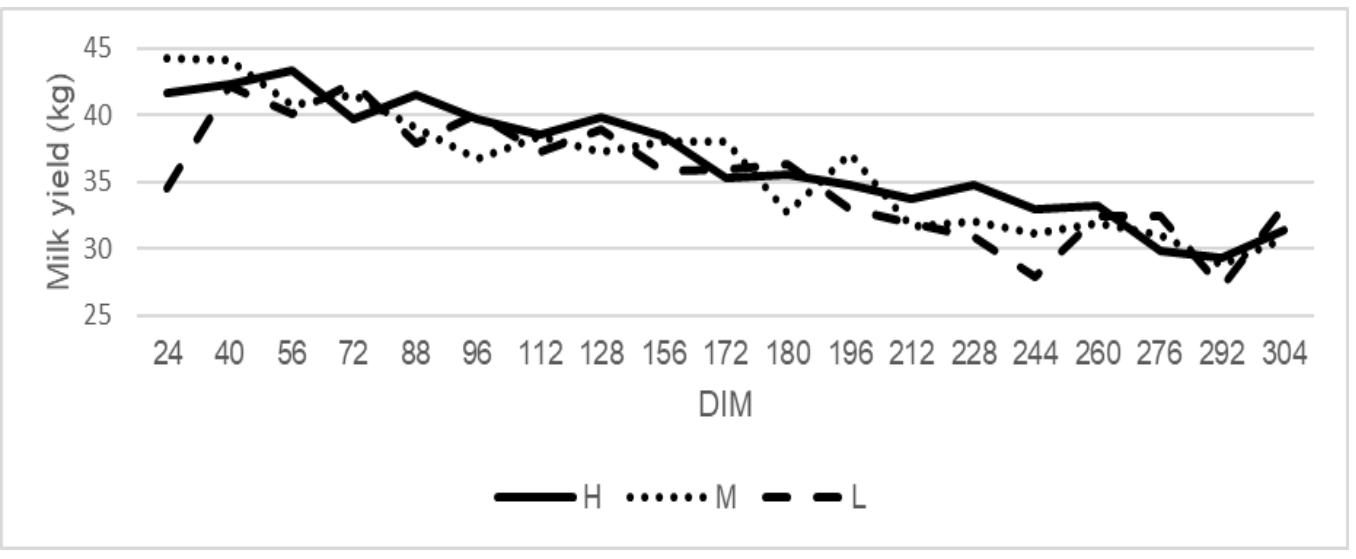

Figure 3. The trend for milk production in cows classified as high (H), medium (M), and low (L) rumination animals. High rumination $(\mathrm{H})$ from $527 \mathrm{~min} /$ day, medium rumination $(\mathrm{M})$ from 412 to $527 \mathrm{~min} /$ day, and low rumination (L) to $412 \mathrm{~min} /$ day.

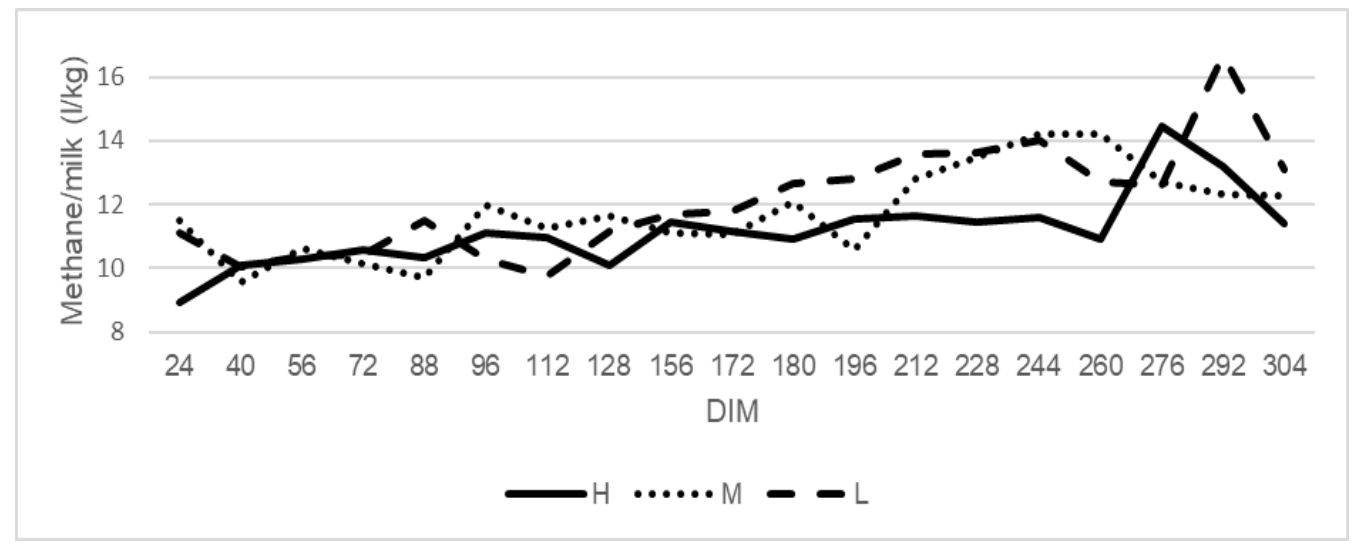

Figure 4. The trend for methane emission on milk production $(\mathrm{CH} 4 / \mathrm{milk})$ in cows classified as high $(\mathrm{H})$, medium $(\mathrm{M})$, and low $(\mathrm{L})$ rumination animals. High rumination $(\mathrm{H})$ from $527 \mathrm{~min} /$ day, medium rumination (M) from 412 to $527 \mathrm{~min} /$ day, and low rumination (L) to $412 \mathrm{~min} /$ day.

\section{Discussion}

We hypothesized that a longer rumination time would be connected with lower daily methane production per milk unit in high-yielding dairy cows fed a partial mixed ration based on maize silage without pasture access. Cows from all the groups $(\mathrm{H}, \mathrm{M}$, and $\mathrm{L})$ ruminated approximately $458 \mathrm{~min}$ per day, which is in the range reported in the literature by White et al. [28], who analyzed 179 cows with a mean rumination time of $436 \mathrm{~min} /$ day, ranging from 236 to $610 \mathrm{~min} /$ day, as well as Zetouni et al. [16], who recorded $443 \mathrm{~min} /$ day as average rumination time during Danish Holstein cows lactation. Cows from the high rumination group ruminated $551 \mathrm{~min} /$ day, which was an $84 \mathrm{~min}$ increase compared to the medium (467 $\mathrm{min} /$ day) and $195 \mathrm{~min}$ more compared to the low ruminating cows (356 min/day). Similar differences of rumination time in grazing cows were reported by Watt et al. [10].

Rumination time had no effect on milk, energy-corrected milk as well as fat and proteincorrected milk production. Despite a positive relationship between rumination time and milk production in early lactation [29] and mid-lactation [4], which has been reported earlier, Stone et al. [30] noted a weak correlation between both phenotypes $(r=0.30)$. The positive relationship between rumination time and milk production may be indirectly related to dry matter intake. Nevertheless, dry matter intake may indirectly cause a positive relationship between rumination time and milk yield, and the association between dry matter intake and rumination time can also depend on diet composition [3]. 
Moreover, Stone et al. [30] explained that the reason for the different results shown by various authors was due to differences in methods of rumination activity detection. In an early study, rumination was estimated based on direct visual observations, and results can be different when measured by an automated rumination logging system [30].

Watt et al. [10] observed a positive association with rumination time and greater milk production, concentrate intake from AMS, as well as estimated dry matter intake by grazing cows. It is commonly known that the main factors of rumination time are connected with the chemical and physical characteristics of the diets, but according to Beauchemin et al. [3], who described a positive relationship between rumination time and dry mater intake in dairy cows, on this basis, we can assume that high rumination cows were also fed a more PMR-based diet. Schirmann et al. [31] showed that cows that ruminated more time per day spent less time feeding $(r=-0.34)$, and rumination times did not relate to dry matter intake $(r=0.11)$. In the present study, differences in concentrate intake across the groups were not detected. Rumination time had a slight effect on milk composition; the cows that ruminated longer $(\mathrm{H})$ had only less fat concentration without differences in protein and lactose concentrations in milk. Similarly, a negative correlation between rumination time and milk fat concentration during the first month of lactation in cows older than the third lactation was noted by Kaufman et al. [9]. It would appear that an increase in rumination time should be directly connected with better rumen homeostasis and fiber microbial degradation and an increase in fat percentage [32]. Less milk fat concentration in high ruminating cows $(\mathrm{H})$ may be connected with their higher milk yield, while it may also be a consequence of the enhanced availability of glucose for the synthesis of lactose in milk without any increase in volatile fatty acids or long-chain fatty acids for butterfat synthesis. Rumination time had no effect on protein concentration in milk, which is in agreement with the observations reported by Kaufman et al. [9], who found no association between milk protein and rumination time in dairy cows during the first month of lactation. Different results, i.e., a negative relationship between rumination time and milk production, protein content in milk, but a positively association with milk fat concentration in a study of mid-lactation Holstein and Swedish Red cows were reported by Byskov et al. [33].

Rumination time had a positive effect on a decrease in methane production; cows assigned to the high ruminating group produced less methane than medium and lower ruminating groups, and medium ruminating cows produced less methane than cows with a lower daily rumination time. A similar result, negative genetic correlation between methane and rumination time was estimated by López-Paredes et al. [15], who collected methane data from 14 to 21-day periods. This results are different from those of Zatouni et al. [16], who observed a lack of relationship between rumination time and methane emission by high-yielding dairy cows. Phenotypes, methane emission, and rumination activity are affected by many factors that are hard to be accounted for, and therefore, the results from other studies can differ. Additionally, it is known that increasing NDF from forages in the dairy cows diets stimulates rumination activity, increases saliva production, and via buffering rumen fluid increases the production of acetate in the rumen, leading to higher methane production [33]. On the other hand, decreasing NDF from forage and an increase in concentrates intake may be associated with a decreased rumen $\mathrm{pH}$, leading to an increase in the levels of propionate and a decrease in acetate and butyrate levels while decreasing hydrogen equivalents that would be converted to methane and are inhibitors in methanogenesis. Different results from current study, higher methane emissions from high ruminating grazing cows were shown by Watt et al. [10]. An explanation of these differences may be attributed to the different body weights of high and low ruminating cows in both experiments. In a study described by Watt et al. [10], high ruminating grazing cows were heavier than low ruminating grazing cows in contrast to the present study, where high ruminating cows had lower body weight. Additionally, the high ruminating cows had lower methane emissions per metabolic body weight than cows that spent less time on rumination. Lower methane production in high ruminating cows per body weight 
may be connected with lower body weight as well as lower methane production by cows from this group.

In the present study, high ruminating cows had a lower daily methane production per milk unit as well as energy-corrected milk than other cows, which spent less time on rumination. A reduction of methane emission per milk production in high ruminating cows with similar milk yield between the three groups is connected only with the lowest methane emission. A reduction of methane production per unit of product was also observed in high ruminating grazing dairy cows [10]. Knapp et al. [14] described that diets containing more energy or with better digestibility increase net energy intake, and when this energy is partitioned into milk production, a decrease in methane emission per ECM yield can be observed. In addition, Aguerre et al. [34] observed a decrease in methane per ECM production when non-fiber carbohydrates were elevated through an increase in concentrate intake from 32 to $53 \%$ in the diet.

We collected 14,274 records of daily methane emissions recorded throughout lactation from 24 to 304 days to obtain high reliability of the daily methane production estimates. Including individual dry matter intake levels would provide additional insights; however, they was not possible to collect due to the very large number of collected observations and technical difficulties. Methane emission measurements are highly variable between animals and within the lactation period. Thus, studies on methane emission should be conducted on a large number of animals and cover a long time period and the association of rumination time that best indicates the physiological state of ruminal fermentation at optimal levels to ensure animal welfare and health.

\section{Conclusions}

In conclusion, the results confirmed the hypothesis that a longer rumination time is related to lower methane emission per milk unit in high-yielding dairy cows fed a partial mixed ration based on maize silage without pasture access.

Author Contributions: Conceptualization, R.M.; methodology, R.M., M.P. and T.S.; software, M.P.; validation, R.M., M.P., K.R., S.M. and T.S.; formal analysis, M.P., K.R., T.S. and R.M.; investigation, M.P., K.R., T.S. and R.M.; resources, T.S.; data curation, R.M., M.P., T.S. and K.R.; writing—original draft preparation, R.M., M.P., K.R., S.M. and T.S.; writing-review and editing, R.M. and M.P.; visualization, R.M. and M.P.; supervision, T.S. and W.N.; project administration, T.S., M.P. and R.M.; funding acquisition, T.S., M.P. and R.M. All authors have read and agreed to the published version of the manuscript.

Funding: The work was supported by the statutory funds of the Faculty of Veterinary Medicine and Animal Science, the Poznan University of Life Sciences (grant No. 506.533.04.00 and 506.534.04.00).

Institutional Review Board Statement: Ethical approval was waived for this study, due to milk samples and methane emission being measured by AMS and having no effect on additional animal stress as well as not requiring a procedure, which should be approved by an Ethical Committee.

Informed Consent Statement: Not applicable.

Data Availability Statement: Data is available at a reasonable request to the corresponding authors.

Acknowledgments: The authors would like to thank Karol Polaszek and the Niechłód farm (Poland) staff for the care, management, and feeding of cows.

Conflicts of Interest: The authors declare that there are no conflicts of interest.

\section{References}

1. Allen, M.S. Relationship between Fermentation Acid Production in the Rumen and the Requirement for Physically Effective Fiber. J. Dairy Sci. 1997, 80, 1447-1462. [CrossRef]

2. Abdela, N. Sub-acute Ruminal Acidosis (SARA) and its Consequence in Dairy Cattle: A Review of Past and Recent Research at Global Prospective. Achiev. Life Sci. 2016, 10, 187-196. [CrossRef]

3. Beauchemin, K.A. Invited review: Current perspectives on eating and rumination activity in dairy cows. J. Dairy Sci. 2018, 101, 4762-4784. [CrossRef] 
4. $\quad$ Liboreiro, D.N.; Machado, K.S.; Silva, P.R.B.; Maturana, M.M.; Nishimura, T.K.; Brandão, A.P.; Endres, M.I.; Chebel, R.C. Characterization of peripartum rumination and activity of cows diagnosed with metabolic and uterine diseases. J. Dairy Sci. 2015, 98, 6812-6827. [CrossRef]

5. Schirmann, K.; Weary, D.M.; Heuwieser, W.; Chapinal, N.; Cerri, R.L.A.; von Keyserlingk, M.A.G. Short communication: Rumination and feeding behaviors differ between healthy and sick dairy cows during the transition period. J. Dairy Sci. 2016, 99, 9917-9924. [CrossRef] [PubMed]

6. Stangaferro, M.L.; Wijma, R.; Caixeta, L.S.; Al-Abri, M.A.; Giordano, J.O. Use of rumination and activity monitoring for the identification of dairy cows with health disorders: Part III. Metritis. J. Dairy Sci. 2016, 99, 7422-7433. [CrossRef]

7. Soriani, N.; Trevisi, E.; Calamari, L.; Parmense, V.E. Relationships between rumination time, metabolic conditions, and health status in dairy cows during the transition period 1. J. Anim. Sci. 2018, 90, 4544-4554. [CrossRef]

8. Clément, P.; Guatteo, R.; Delaby, L.; Rouillé, B.; Chanvallon, A.; Philipot, J.M.; Bareille, N. Short communication: Added value of rumination time for the prediction of dry matter intake in lactating dairy cows. J. Dairy Sci. 2014, 97, 6531-6535. [CrossRef]

9. Kaufman, E.I.; Asselstine, V.H.; LeBlanc, S.J.; Duffield, T.F.; DeVries, T.J. Association of rumination time and health status with milk yield and composition in early-lactation dairy cows. J. Dairy Sci. 2017, 101, 462-471. [CrossRef]

10. Watt, L.J.; Clark, C.E.F.; Krebs, G.L.; Petzel, C.E.; Nielsen, S.; Utsumi, S.A. Differential rumination, intake, and enteric methane production of dairy cows in a pasture-based automatic milking system. J. Dairy Sci. 2015, 98, 7248-7263. [CrossRef]

11. Grešáková, L'.; Holodová, M.; Szumacher-Strabel, M.; Huang, H.; Ślósarz, P.; Wojtczak, J.; Sowińska, N.; Cieślak, A. Mineral status and enteric methane production in dairy cows during different stages of lactation. BMC Vet. Res. 2021, 17, 287. [CrossRef] [PubMed]

12. Kozłowska, M.; Cieślak, A.; Jóźwik, A.; El-Sherbiny, M.; Gogulski, M.; Lechniak, D.; Gao, M.; Yanza, Y.R.; Vazirigohar, M.; Szumacher-Strabel, M. Effects of partially replacing grass silage by lucerne silage cultivars in a high-forage diet on ruminal fermentation, methane production, and fatty acid composition in the rumen and milk of dairy cows. Anim. Feed Sci. Technol. 2021, 277, 114959. [CrossRef]

13. Huang, H.; Szumacher-Strabel, M.; Patra, A.K.; Ślusarczyk, S.; Lechniak, D.; Vazirigohar, M.; Varadyova, Z.; Kozłowska, M.; Cieślak, A. Chemical and phytochemical composition, in vitro ruminal fermentation, methane production, and nutrient degradability of fresh and ensiled Paulownia hybrid leaves. Anim. Feed Sci. Technol. 2021, 279, 115038. [CrossRef]

14. Knapp, J.R.; Laur, G.L.; Vadas, P.A.; Weiss, W.P.; Tricarico, J.M. Invited review: Enteric methane in dairy cattle production: Quantifying the opportunities and impact of reducing emissions. J. Dairy Sci. 2014, 97, 3231-3261. [CrossRef] [PubMed]

15. López-Paredes, J.; Goiri, I.; Atxaerandio, R.; García-Rodríguez, A.; Ugarte, E.; Jiménez-Montero, J.A.; Alenda, R.; González-Recio, O. Mitigation of greenhouse gases in dairy cattle via genetic selection: 1. Genetic parameters of direct methane using noninvasive methods and proxies of methane. J. Dairy Sci. 2020, 103, 7199-7209. [CrossRef] [PubMed]

16. Zetouni, L.; Difford, G.F.; Lassen, J.; Byskov, M.V.; Norberg, E.; Løvendahl, P. Is rumination time an indicator of methane production in dairy cows? J. Dairy Sci. 2018, 101, 11074-11085. [CrossRef]

17. Denninger, T.M.; Dohme-Meier, F.; Eggerschwiler, L.; Vanlierde, A.; Grandl, F.; Gredler, B.; Kreuzer, M.; Schwarm, A.; Münger, A. Persistence of differences between dairy cows categorized as low or high methane emitters, as estimated from milk mid-infrared spectra and measured by GreenFeed. J. Dairy Sci. 2019, 102, 11751-11765. [CrossRef] [PubMed]

18. Kononoff, P.J.; Heinrichs, A.J.; Buckmaster, D.R. Modification of the Penn State Forage and Total Mixed Ration Particle Separator and the Effects of Moisture Content on its Measurements. J. Dairy Sci. 2003, 86, 1858-1863. [CrossRef]

19. Reist, M.; Erdin, D.K.; Von Euw, D.; Tschümperlin, K.M.; Leuenberger, H.; Hammon, H.M.; Morel, C.; Philipona, C.; Zbinden, Y.; Künzi, N.; et al. Postpartum reproductive function: Association with energy, metabolic and endocrine status in high yielding dairy cows. Theriogenology 2003, 59, 1707-1723. [CrossRef]

20. Centraal Veevoederbureau (CVB). Tabellenboek Veevoeding: Voedernormen Landbouwhuisdieren en Voederwaarde Veevoeders; Productschap Diervoeder: Den Haag, The Netherlands, 2012.

21. Pszczola, M.; Rzewuska, K.; Mucha, S.; Strabel, T. Heritability of methane emissions from dairy cows over a lactation measured on commercial farms. J. Anim. Sci. 2017, 95, 4813-4819. [CrossRef]

22. Madsen, J.; Bjerg, B.S.; Hvelplund, T.; Weisbjerg, M.R.; Lund, P. Methane and carbon dioxide ratio in excreted air for quantification of the methane production from ruminants. Livest. Sci. 2010, 129, 223-227. [CrossRef]

23. R Core Team. R: A Language and Environment for Statistical Computing; R Foundation for Statistical Computing: Vienna, Austria, 2021; Available online: https:/ / www.R-project.org/ (accessed on 1 June 2021).

24. Bates, D.; Mächler, M.; Bolker, B.M.; Walker, S.C. Fitting linear mixed-effects models using lme4. J. Stat. Softw. 2015, 67, 1-48. [CrossRef]

25. Kuznetsova, A.; Brockhoff, P.B.; Christensen, R.H.B. lmerTest Package: Tests in Linear Mixed Effects Models. J. Stat. Softw. 2017, 82, 1-26. [CrossRef]

26. Lenth, R.V. Emmeans: Estimated Marginal Means, Aka Least-Squares Means; R package version 1.7.0. Available online: https: / / cran.r-project.org/package=emmeans (accessed on 1 June 2021).

27. Fai, A.H.T.; Cornelius, P.L. Approximate f-tests of multiple degree of freedom hypotheses in generalized least squares analyses of unbalanced split-plot experiments. J. Stat. Comput. Simul. 1996, 54, 363-378. [CrossRef]

28. White, R.R.; Hall, M.B.; Firkins, J.L.; Kononoff, P.J. Physically adjusted neutral detergent fiber system for lactating dairy cow rations. II: Development of feeding recommendations. J. Dairy Sci. 2017, 100, 9569-9584. [CrossRef] [PubMed] 
29. Soriani, N.; Panella, G.; Calamari, L. Rumination time during the summer season and its relationships with metabolic conditions and milk production. J. Dairy Sci. 2013, 96, 5082-5094. [CrossRef]

30. Stone, A.E.; Jones, B.W.; Becker, C.A.; Bewley, J.M. Influence of breed, milk yield, and temperature-humidity index on dairy cow lying time, neck activity, reticulorumen temperature, and rumination behavior. J. Dairy Sci. 2017, 100, 2395-2403. [CrossRef]

31. Schirmann, K.; Chapinal, N.; Weary, D.M.; Heuwieser, W.; von Keyserlingk, M.A.G. Rumination and its relationship to feeding and lying behavior in Holstein dairy cows. J. Dairy Sci. 2012, 95, 3212-3217. [CrossRef]

32. Zebeli, Q.; Aschenbach, J.R.; Tafaj, M.; Boguhn, J.; Ametaj, B.N.; Drochner, W. Invited review: Role of physically effective fiber and estimation of dietary fiber adequacy in high-producing dairy cattle. J. Dairy Sci. 2012, 95, 1041-1056. [CrossRef]

33. Byskov, M.V.; Nadeau, E.; Johansson, B.E.O.; Nørgaard, P. Variations in automatically recorded rumination time as explained by variations in intake of dietary fractions and milk production, and between-cow variation Variations in automatically recorded rumination time as explained by variations in intake of die. J. Dairy Sci. 2015, 98, 3926-3937. [CrossRef]

34. Aguerre, M.J.; Wattiaux, M.A.; Powell, J.M.; Broderick, G.A.; Arndt, C. Effect of forage-to-concentrate ratio in dairy cow diets on emission of methane, carbon dioxide, and ammonia, lactation performance, and manure excretion. J. Dairy Sci. 2011, 94, 3081-3093. [CrossRef] [PubMed] 